\title{
Coronavirus (COVID-19)- A Pandemic Causing Global Lockdown
}

\author{
Khan NT* \\ Department of Biotechnology, Balochistan University of Information Technology Engineering \\ and Management Sciences, Pakistan
}

*Corresponding author: Nida Tabassum Khan, Department of Biotechnology, Faculty of Life Sciences and Informatics, Balochistan University of Information Technology Engineering and Management Sciences, (BUITEMS), Quetta, Pakistan, Email: nidatabassumkhan@yahoo.com

\section{Review Article}

Volume 4 Issue 3

Received Date: April 15, 2020

Published Date: May 11, 2020

DOI: $10.23880 /$ eij-16000147

\section{Abstract}

COVID-19 is caused by the virus SARS-CoV-2 and appeared in Wuhan, China, in late 2019. It is characterized by the appearance of symptoms such as pneumonia or bronchitis. The virus seems to usually cause a milder infection in children than in adults or older people. Currently no treatment or cure is available for COVID-19 and development of a vaccine is currently under trial. However in order to prevent the spread of COVID-19 infection, it is recommended to avoid contact with the infected individual and observed social distancing.

Keywords: Furin; Bronchitis; Pneumonia; Chloroquine; Remdesivir; Spike proteins

Abbreviations: SARS-CoV: Severe Acute Respiratory Syndrome Coronavirus.

\section{Introduction}

Cases of SARS-CoV (severe acute respiratory syndrome coronavirus) infection was first reported in Guangdong City, China in 2002 as an uncommon life-threatening pneumonia leading to respiratory failure in many cases $[1,2]$. The virus quickly spread from continent to continent affecting 29 countries resulting in an infection of approximately more than 8000 people $[3,4]$. Coronaviruses are enveloped, single stranded RNA viruses containing approximately 26,000 to 32,000 bases [5]. There are seven human coronaviruses such as HCoV-HKU1, HCoV-229E, HCoV-OC43, HCoV-OC43, SARSCoV, HCoV-229E and HCoV-NL63 [6,7]. COVID-19 is caused by the virus SARS-CoV-2 [8] and appeared in Wuhan, China, in late 2019 [9]. Since the outbreak it spread across China to other countries and has been declared a public health emergency of international concern by the WHO [10].

\section{COVID-19 Structure}

SARS-CoV-2 is spreading at an exponential rate resulting in 82,000 infections following 2,800 deaths within two months since its outbreak [11]. And globally,
168,000 COVID-19 infections have been identified [12]. The microscopic structure of the virus SARS-CoV-2 reveals that it has a surface protein known as spike protein (upto1255 amino acids) that binds tightly to the receptors (ACE2) of its host cells to produce infection [13]. The binding mechanism is aided by a specific host cell enzyme known as furin which is present in most of human organs such as intestine, liver, lungs etc. Thus allowing the virus to easily attack multiple organs at once [14]. The furin cleavage site in SARS-CoV-2 spike proteins also contributes towards virus stability and easy transmission [15].

\section{COVID-19 Spread}

Coronaviruses are transmitted from animals to humans i.e. zoonotic [16]. COVID-19 may have been passed from bats to another animal and then to humans as the researcher believes [17]. Its transmission was reported to in the open sea food market in Wuhan, China [18].

\section{COVID-19 Symptoms}

The apparent symptoms of COVID-19 are sore throat, fever, cough, pneumonia, respiratory illnesses such as nasal obstruction, bronchitis, cilia damage, alveolar interstitial fiber cell hyperplasia, fibrotic lung disease etc. [19,20]. 


\section{Epidemiology International Journal}

\section{COVID-19 Diagnosis}

COVID-19 infection is diagnosed in patients using their blood, saliva, or nostrils sample [21]. In addition, coronavirus fully automated RT-PCR testing kits currently is the gold standard for diagnosis [22].

\section{COVID-19 Complications}

The virus seems to usually cause a milder infection in children than in adults or older people [23]. One of the most severe complications of COVID-19 infection is the symptom of pneumonia that causes severe acute respiratory distress syndrome, fatigue, arrhythmia, myalgia, heart attack and severe muscle pain leading to the death of the infected $[24,25]$. Moreover studies reported that this virus is gradually mutating thus decreasing the chance of it altering to become more fatal [26].

\section{COVID-19 Prevention}

In order to prevent the spread of COVID-19 infection, it is advisable to avoid contact with the infected individual. In addition social distancing is recommended [27]. On the other hand personal hygiene should be maintained following hand washing with a soap for 20 seconds which will break viral membrane [28], use of disinfectants for cleaning, wearing masks when going outside to prevent exposure, avoid gatherings during infection breakout, use $60 \%$ alcohol containing sanitizer at all times etc. [29]. Ultraviolet light and heat disrupts the genetic material (RNA) of the virus and its spike proteins structural integrity respectively [30,31].

\section{COVID-19 Treatment}

Currently no treatment or cure is available for COVID-19 and development of a vaccine is currently under trial [32]. In case an individual is diagnosed with such an infection, treatment is focused on reducing the apparent symptoms of the disease such as using retroviral medications, steroids, blood plasma transfusions etc [33]. In addition, research on designing furin inhibitors and blocking ACE2 receptors may be another viable solution to stop this virus [34]. And likelihood of developing antibodies against COVID-19 is also under investigation [35]. There are presently no precise drugs treatments for this virus. However HIV drugssuch as lopinavir and ritonavir [36], antimalarial drugs such as chloroquine and antiEbola drug such as remdesivir [37] are being tested in COVID-19 infected individuals.

\section{Conclusion}

Thus COVID-19 is a pandemic causing global lockdown. However by improving personal hygiene and following social distancing we can prevent its spread.

\section{References}

1. Zhong NS, Zheng BJ, Li YM, Poon, Xie ZH, et al. (2003) Epidemiology and cause of severe acute respiratory syndrome (SARS) in Guangdong, People's Republic of China, in February, 2003. Lancet 362(9393): 1353-1358.

2. Centers for Disease Control and Prevention (2003) Prevalence of IgG antibody to SARS-associated coronavirus in animal traders--Guangdong Province, China, 2003. MMWR Morb Mortal Wkly Rep 52(41): 986-987.

3. Bolles M, Donaldson E, Baric R (2011) SARS-CoV and emergent coronaviruses: viral determinants of interspecies transmission. Curr Opin Virol 1(6): 624634.

4. Wang LF, Shi Z, Zhang S, Field H, Daszak P, et al. (2006) Review of bats and SARS. Emerg Infect Dis 12(12): 18341840 .

5. Brian DA, Baric RS (2005) Coronavirus genome structure and replication. Curr Top Microbiol Immunol 287: 1-30.

6. van der Hoek L, Pyrc K, Jebbink MF, Vermeulen-Oost W, Berkhout RJ, et al. (2004) Identification of a new human coronavirus. Nat Med 10(4): 368-373.

7. To KK, Hung IF, Chan JF, Yuen KY (2013) From SARS coronavirus to novel animal and human coronaviruses. J Thorac Dis 5(2): 103-108.

8. Bai Y, Yao L, Wei T, Tian F, Jin DY, et al. (2020) Presumed asymptomatic carrier transmission of COVID-19. Jama.

9. Novel CPERE (2020) The epidemiological characteristics of an outbreak of 2019 novel coronavirus diseases (COVID-19) in China. Zhonghua Liu Xing Bing Xue Za Zhi 41(2): 145-151.

10. World Health Organization (2020) Coronavirus disease 2019 (COVID-19): situation report.

11. Rezaeetalab F, Mozdourian M, Amini M, Javidarabshahi Z, Akbari F (2020) COVID-19: A New Virus as a Potential Rapidly Spreading in the Worldwide. Journal of CardioThoracic Medicine 8(1): 563-564.

12. Balla M, Merugu GP, Patel M, Koduri NM, Gayam V, et al. (2020) COVID-19, Modern Pandemic: A Systematic Review From a Front-Line Health Care Providers' Perspective. Journal of Clinical Medicine Research, 12(4): 215-229.

13. Walls AC, Park YJ, Tortorici MA, Wall A, McGuire AT, et al. (2020) Structure, function, and antigenicity of the SARS- 
CoV-2 spike glycoprotein. Cell 48(2): 281-292.

14. Yan R, Zhang Y, Li Y, Xia L, Guo Y, et al. (2020) Structural basis for the recognition of SARS-CoV-2 by full-length human ACE2. Science 367(6485): 1444-1448.

15. Prabakaran P, Xiao X, Dimitrov DS (2004) A model of the ACE2 structure and function as a SARS-CoV receptor. Biochemical and biophysical research communications 314(1): 235-241.

16. Sheahan T, Rockx B, Donaldson E, Sims A, Pickles R, et al. (2008) Mechanisms of zoonotic severe acute respiratory syndrome coronavirus host range expansion in human airway epithelium. Journal of virology 82(5): 2274-2285.

17. Ahmad T, Khan M, Haroon, Musa TH, Nasir S, et al. (2020) COVID-19: Zoonotic aspects. Travel Medicine and Infectious Disease.

18. Wu YC, Chen CS, Chan YJ (2020) The outbreak of COVID-19: An overview. Journal of the Chinese Medical Association 83(3): 217-220.

19. Rothan HA, Byrareddy SN (2020) The epidemiology and pathogenesis of coronavirus disease (COVID-19) outbreak. Journal of autoimmunity 109: 102433.

20. Shi H, Han X, Jiang N, Cao Y, Alwalid O, et al. (2020) Radiological findings from 81 patients with COVID-19 pneumonia in Wuhan, China: a descriptive study. The Lancet Infectious Diseases 20(4): 425-434.

21. Adhikari SP, Meng S, Wu YJ, Mao YP, Ye RX, et al. (2020) Epidemiology, causes, clinical manifestation and diagnosis, prevention and control of coronavirus disease (COVID-19) during the early outbreak period: a scoping review. Infectious diseases of poverty 9(1): 1-12.

22. Pfefferle S, Reucher S, Nörz D, Lütgehetmann M (2020) Evaluation of a quantitative RT-PCR assay for the detection of the emerging coronavirus SARS-CoV-2 using a high throughput system. Euro Surveill 25(9).

23. Ludvigsson JF (2020) Systematic review of COVID-19 in children show milder cases and a better prognosis than adults. Acta Paediatrica 1-8.

24. Hellewell J, Abbott S, Gimma A, Bosse NI, Jarvis CI, et al. (2020) Feasibility of controlling COVID-19 outbreaks by isolation of cases and contacts. The Lancet Global Health 8(4): 488-496.

25. Wu JT, Leung K, Bushman M, Kishore N, Niehus R, et al. (2020) Estimating clinical severity of COVID-19 from the transmission dynamics in Wuhan, China. Nature Medicine 20: 506-510.

\section{Epidemiology International Journal}

26. Zhao Z, Li H, Wu X, Zhong, Y, Zhang K, et al. (2004) Moderate mutation rate in the SARS coronavirus genome and its implications. BMC evolutionary biology 4: 21 .

27. Watkins J (2020). Preventing a covid-19 pandemic.

28. World Health Organization (2020) Rational use of personal protective equipment for coronavirus disease (COVID-19): interim guidance.

29. Oosterhoff B, Palmer CA (2020) Psychological correlates of news monitoring, social distancing, disinfecting, and hoarding behaviors among US adolescents during the COVID-19 pandemic: 1-20.

30. Cascella M, Rajnik M, Cuomo A, Dulebohn SC, Di Napoli R (2020). Features, evaluation and treatment coronavirus (COVID-19). StatPearls.

31. Chan KW, Wong VT, Tang SCW (2020) COVID-19: An Update on the Epidemiological, Clinical, Preventive and Therapeutic Evidence and Guidelines of Integrative Chinese-Western Medicine for the Management of 2019 Novel Coronavirus Disease. The American journal of Chinese medicine 13: 1-26.

32. Fauci AS, Lane HC, Redfield RR (2020) Covid-19navigating the uncharted 382: 1268-1269.

33. Murthy S, Gomersall CD, Fowler RA (2020) Care for critically ill patients with COVID-19. Jama 323(15): 1499-1500.

34. Li X, Geng M, Peng Y, Meng L, Lu S (2020) Molecular immune pathogenesis and diagnosis of COVID-19. Journal of Pharmaceutical Analysis 10(2): 102-108.

35. Chen L, Xiong J, Bao L, Shi Y (2020) Convalescent plasma as a potential therapy for COVID-19. The Lancet Infectious Diseases 20(4): 398-400.

36. Dong L, Hu S, Gao J (2020) Discovering drugs to treat coronavirus disease 2019 (COVID-19). Drug discoveries \& therapeutics 14(1): 58-60.

37. Wang M, Cao R, Zhang L, Yang X, Liu J, et al. (2020) Remdesivir and chloroquine effectively inhibit the recently emerged novel coronavirus (2019-nCoV) in vitro. Cell research 30(3): 269-271. 